\title{
THE FIRST DEPARTMENT OF MUSEOLOGY IN ST. PETERSBURG: A 30-YEAR-LONG PATH
}

30 years is a significant occasion to turn to the past, reflect on the present and try to get a glimpse of the future. Established in the year of the 70th anniversary of the Institute, the Department of Museology and Cultural Heritage celebrates its 30th anniversary simultaneously with the centenary of St. Petersburg State Institute of Culture. The coincidence of two memorable dates makes it possible, on the one hand, to assess objectively the process of development of the department, which was the first in Russia to train museum specialists, and, on the other hand, to do it in the context of development of a higher educational institution, where repeated attempts have been taken to train students for future work in museums. And it was in this educational institution, which, as well as the department, has changed its name on several occasions, that these attempts were successful.

\section{Stages of History}

\section{8: the Beginning of the Path}

A year after the Bolshevik

Revolution of 1917, a newly created Institute of Further Education (as originally the higher educational institution was called) in Petrograd "accounted for the department of museology and two specialties: museum and excursion activities. However, it did not exist for a long time, as financial difficulties required the reduction of activities of the young institute." ${ }^{1}$ The data related to this period has not been preserved.

\section{7-1942: the Second Attempt}

The attention of the Soviet authorities to the training of employees for museums was determined by the strive to provide the country with "new staff" capable of carrying out a "socialist reconstruction" of the museum activities. In this connection, in 1937, "the Department of Museum Studies, which in January, 1942 held the first and the last graduation ceremony, [...] was revived as part of Leningrad Political-Educational Communist Institute." ${ }^{2}$ In the process of reorganization of the educational institution into the Library Institute the Department of Museum Studies was closed and ceased to exist.

\section{8: Department of Museum Activities and Protection of Monuments}

In other higher educational establishments of Russia numerous attempts to organize training of museum specialists were made. However, a genuine revival of a museum specialty in post-perestroika period was accomplished only after long-term

\footnotetext{
1 SERGEEVA, Nadezhda I. Introductory article. In Museum and tourism: staff training. Experience and perspectives. Collection of materials of all-Russian scientific-practical conference 19-21 April 2004, devoted to 15th anniversary of the Department and 10th anniversary of the Faculty of Museum Studies and Excursion Guiding. St. Petersburg: St. Petersburg State University of Culture and Arts, 2005, pp. 3-5.

2 Ibid.
}

and persistent efforts, when in 1988 simultaneously "departments of Museum Studies were created in Leningrad State Institute of Culture (reorganised from Leningrad Library Institute), in Moscow State Historico-Archival Institute, later in Moscow State Institute of Culture."3

Establishing the Department of Museum Studies in Leningrad State Institute of Culture was, on the one hand, the result of political, ideological and socio-cultural transformations which affected educational guidelines, having changed the status of museological education due to the recognition of museology as an independent science. This was largely facilitated by the establishment in 1977 of the International Committee for Museology (ICOFOM) within the International Council of Museums (ICOM) and teaching museology as an independent science in leading universities in various countries. On the other hand, the establishment of the department can be rightfully considered the result of a personal initiative and efforts of the veteran of the Institute of Culture, who had worked in the institute for 57 years, the Candidate of Historical Sciences, the Honoured Worker of the Higher School of Russia, the Honorary Professor of the Institute Nadezhda Ivanovna Sergeeva (1920-2011).

The gist and concepts of training museum experts museologists have been still debated, reflecting the

3 Ibid. 
discussion level of comprehension of the emerging science, and many aspects have remained open so far. The controversy of the issue is specified by the complexities in training of an integrated, if not a universal specialist, as well as by the novelty of a profession designated for the first time.

The educational strategies and the concept of training museum specialists in St. Petersburg State Institute of Culture was initially based on the understanding of museology, belonging to the outstanding Czech researcher Zbyněk Z. Stránský (1926-2016). ${ }^{4}$ Museology, in his opinion, is cognition of such documents that optimally represent renowned social values and are sufficient cause to be selected, treasured up and used for communication in the interests of further development of the society. ${ }^{5}$

In other words, this science is connected with the study of the specific, axiological-cognitive (museum) attitude of a person towards reality. In different historical periods this attitude was manifested through various forms of museum institutions. Kunstkammer, show-rooms, anatomical theaters, galleries, museums and modern heritage centers, museum-type institutions, economuseums are integral part of the system of social memory. This means that museology has a historically determined and clearly expressed interdisciplinary

4 GUBARENKO, Maria Ya. and Lyudmila M. SHLYAKHTINA. The genesis and formation

of museology in the Czech Republic and its influence on domestic scientific tradition. Problems of museology, 2015, no. (2) 12, pp. 3-16; GUBARENKO, Maria Ya. The influence of Z. Z. Stránskýs ideas on the formation of the scientific school of the Department of Museology and Cultural Heritage of Saint Petersburg State Institute of Culture. Museologica Brunensia, 2016 , vol. 5, no. 2, pp. 82-84.

5 STRÁNSKÝ, Zbyněk. Die theoretischen Grundlagen der Museologie als Wissenschaft. In Museologie: Neue Wege - Neue Ziele. München [u. a.], 1989, p. 42. character of a science developing dynamically, which is crucially important for education, in which the interrelation between the training of museum specialists and the level of development of scientific views on the museum and museality plays a substantial role. ${ }^{6}$

The necessity of knowledge in the field of various sciences for the future of a museum specialist is determined by the fact that a museum is the object of museology. The field-specific variety of museum institutions predetermines contacts of museology with history, archeology, ethnology, art criticism, literary criticism, zoology, biology, paleontology, mineralogy, geology and other sciences related to the content of museum collections and, therefore, suggests knowledge of future specialists in these fields.

In this regard, training of museum specialists was based on a profound study of social sciences and humanities, which means that the department carried out and has been carrying out the educational process in close cooperation with other departments of the Institute: the Department of History and St. Petersburg Studies, the Department of Literature and Children's Reading, the Department of Theory and History of Culture, the Department of Foreign Languages and Linguistics, the Department of Psychology and Pedagogy, the Department of Mathematics and Information Science, etc. It won' $t$ be exaggeration to say that general scientific knowledge not only enriches students promoting personal growth and

6 MASTENITSA, Elena N. and Lyudmila M. SHLYAKHTINA. Institutionalization of science as a factor of development of museological education. In SIZOVA, I. A. (ed.). World cultural heritage and museums: history, problems and perspectives: materials of All-Russian scientific-practical conference with international participation (Tomsk, 18-20 May, 2017). Tomsk: Tomsk University Publishers, 2017, pp. 74-82. intellectual development, but also has allowed them to demonstrate high achievements at student competitions in humanities at the city, regional and national levels.

\section{2: Department of Museum Studies and Excursion Guiding}

Since 1992, the Institute of Culture was authorized to train guides by a special letter of the Ministry of Culture of the RSFSR, due to which the Department of Museum Studies and Monument Protection was renamed the Department of Museum Studies and Excursion Guiding. For teaching the disciplines in excursion guiding well-known specialists and brilliant guides were invited: N. N. Garshina, G. A. Leskova, T. G. Milova, V. P. Porshnev, who had to create the syllabi of new courses and methodological support for them.

Nowadays we can confidently admit that at the department in the process of joint pedagogical activity of the faculty, a methodological school of excursion guiding has been established, which is keen on preserving and developing traditions of Leningrad excursion guiding school on the basis of achievements in pedagogical science and mastering advanced experience in excursion activities.

The acknowledged leader of the school is Natalya Nikolayevna Garshina, Senior Lecturer, the Honoured Worker of Higher Professional Education of the Russian Federation, a member of the Expert and Methodological Council for the Accreditation of Guides and Guides-Interpreters in St. Petersburg. Ideas and realities of the museum world served as the basis for selecting specializations offered in connection with the transition to the State Educational Standard of the second generation (2002). 
A choice of innovative profiles for training specialists can serve a convincing proof of this. The museological profile put into practice training for the following specializations: "Museum pedagogy: recreational-educational activities of museums", "Attribution of museum items", "Information technologies in the museum", "Museumification of natural and historical-cultural heritage", "Museum and exhibition design", "Management and marketing of collection, exhibition and antiquarian activities". The excursion guiding profile course provided training in specializations: "Excursion guiding with two foreign languages proficiency", "Management of excursion -tourist activity", "Regional excursion guiding", "Intercultural communications of business tourism". It was possible to carry out training in such a wide range of specialties only due to the fact that in 1994, the Department of Museum Studies and Excursion Guiding opened a non-budgetary faculty, the Dean of which (prior to the reorganization of the institute's structure in 2012) was V. P. Yakovlev, the Candidate of Historical Sciences, Professor, the Honoured Worker of Culture of the Russian Federation. For their outstanding contribution to the development of the museum activities of St. Petersburg in the sphere of specialist training, N. I. Sergeeva and V. P. Yakovlev were awarded with special prizes at the annual "Museum Olympus" contest held in St. Petersburg.

Educational strategies at the Department of Museology and Cultural Heritage have always been closely connected with the scientific research of its faculty, were based on serious studies, the quality and quantity of which has steadily increased. Due to introducing a postgraduate course in the new profile in the nomenclature of scientific specialties - "24.00.03. Museology, Conservation and Restoration of Historical and Cultural Objects"during the time of existence of the Department 52 dissertations have been prepared and defended, 5 of them for the academic degree of Doctor of Cultural Studies. Ideas of historical theoretical and applied museology have been observed and continue to be traced in the activities of several generations of students and followers, which makes it possible to admit the beginning of formation of a museological scientific school. ${ }^{7}$

\section{Valentin Petrovich Gritskevich} (1933-2013), Doctor of Cultural Studies, Professor, the Honoured Professor of St. Petersburg State Institute of Culture, a member of the Union of Belarussian Writers, an Honorary member of the International Association of Scholars of Belorussia, a member of the International Academy of Europe and Asia, contributed greatly to the formation and development of the department, to devising the concept and methodology of teaching museological disciplines. His research laid the foundation for historical museology. He is known to modern museologists as the author of a three-volume study of the world history of museum activities, a monograph on history of tourism in antiquity, articles on source studies and historiography of history of the world museums; on methodology of teaching museological disciplines. Those who defended dissertations for the academic degree of the candidate of science under his guidance - V. P. Porshnev, I. A. Kuklinova, O. E. Cherkaeva,

\footnotetext{
7 SHLYAKHTINA, Lyudmila M. and Elena N. MASTENITSA. Formation of the scientific school of the Department of Museology and Cultural Heritage of St. Petersburg State Institute of Culture. In Bulletin of St. Petersburg University of Culture and Arts. Academic journal, 2016, no. 3 (28), pp. 116-121.
}

E. Yu. Shaina, S. Yu. Kurnosov have continued in their works research practices in the field of historical museology, and Associate Professor I. A. Kuklinova has been productively developing pedagogical ideas of her teacher at the Department of Museology and Cultural Heritage. ${ }^{8}$

Development of ideas of theoretical museum studies obtained in the course of training can be evidentially traced in the works of S. V. Pshenichnaya, O. S. Sapanzha, A. Yu. Volkovich, Yu. V. Zinovieva, L. A. Klimov, A. V. Chugunova, M. V. Saltanova and many other graduates of the department who have succeeded both in the practical museum field, and in scientific and pedagogical activities. Undoubtedly, the candidate of pedagogical sciences, Associate Professor, the Honored Worker of the Higher School of the Russian Federation, L. M. Shlyakhtina should be credited for the formation of museology as a scientific and academic discipline. For the first time in Russia she devised the course "Theoretical Problems of Museum Studies“, which has been read at the department since its foundation. Of particular value are L. M. Shlyahtina's achievements in creating the scientific and methodological basis for teaching theoretical museology, implemented in the student training manual "Basics of Museum Activities. Theory and Practice". ${ }^{9}$ The training manual is widely used in the educational process by higher education institutions of the Russian Federation. Years of joint research and pedagogical

\footnotetext{
8 KUKLINOVA Irina A. The concept of world history of museum activities in works of V. P. Gritskevich. In Bulletin of St. Petersburg University of Culture and Arts. Academic journal, 2016, no. 3 (28), pp. 112-115.

9 SHLYAKHTINA, Lyudmila M. Basics of Museum Activities: Theory and Practice. St. Petersburg: Publishing House "Lan"; Publishing House "Planetamusyki", 2016. 248 p.
} 
activities of L. M. Shlyakhtina and E. N. Mastenitsa have proved to be fruitful. In co-authorship, they have written 30 scientific articles, a course book, a monograph "Museum-pedagogical thought in Russia. Historical Essays", which became one of the first historical-theoretical studies in the field of museum pedagogy. ${ }^{10}$

In addition to problems of cultural and educational activities of museums, the Candidate of Historical Sciences, Associate Professor E. N. Mastenitsa has been carrying out research in such directions as history and current state of literary museums, museumification of cultural heritage, methodology of its interpretation and ways of actualization, transformation of the museum phenomenon in the era of globalization. She authored the course "Museum Reserves", supported with a student training manual. ${ }^{11}$ Under the guidance of E. N. Mastenitsa were prepared and successfully defended dissertations for the academic degree of the candidate of sciences by her students and followers: G. P. Sergeeva, N. A. Nikitina, L. N. Bakayutova, M. G. Hugayeva, M. V. Saltanova, Yu. Yu.Oganesova, K. F. Katkova. Currently E. N. Mastenitsa, who has been working at the department since 1993, is Head of Department.

Actual trends and changes in the development of the museum world have always served as a benchmark for the work of the department

10 SHLYAKHTINA, Lyudmila M. and Elena N. MASTENITSA. Museum-pedagogical thought in Russia. Historical Essays. St. Petersburg: St. Petersburg State University of Culture and Arts, 2006. $271 \mathrm{p}$

11 MASTENITSA, Elena N. Museum Reserves: a student training manual for bachelor's profile 51.03.04 "Museology and Protection of Objects of Cultural and Natural Heritage": Ministry of Culture of RF, St. Petersburg State Institute of Culture, Faculty of World Culture, Department of Museology and Cultural Heritage. St. Petersburg: St. Petersburg State Institute of Culture, 2015. $132 \mathrm{p}$. and determined close connection of the educational process with life of large and small museums in St. Petersburg. The State Hermitage Museum, the State Russian Museum, the Russian Ethnographic Museum, the All-Russian Museum of Alexander Pushkin, the State Museum of the History of Religion, the State Museum of the History of St. Petersburg, the Military History Museum of Artillery, Engineer and Signal Corps, the Military Medical Museum of the Defense Ministry of the Russian Federation, the a. s. Popov Central Museum of Communications, the F. M. Dostoevsky Literary and Memorial Museum, the A. A. Akhmatova Museum-Apartment in Fontanny House, and many others have not only served for many years as bases for practice training, but also acted as partners and enthusiastic employers. This interaction has always been recognized as important and was carried out in the educational process by attracting distinguished experts who are working in museums, scientific institutions and tourist companies in St. Petersburg. Prominent scholars and professionals always generously share their extensive knowledge and invaluable experience with students.

For a quarter of a century the department trained specialists in two profiles: museum studies and excursion guiding. They formed knowledge, skills and know-how necessary to meet challenges of the rapidly changing museum world and for development of cultural and educational tourism. At the beginning of the XXI century, the Russian system of higher education began to take a clear shape, corresponding to the requirements of the postindustrial society. Labour market orientation and development of the Bologna process predetermined the need for reforms of the Russian education and development of new educational strategies. In this regard, for training of bachelors (2009), and then for training of masters (2010), the Ministry of Education and Science of the Russian Federation approved and put into effect a unified Federal State Educational Standard in the field of "Museology and Protection of Objects of Natural and Cultural Heritage" which became the initial document for reorganization of training of museologists for transition to a multilevel system of education.

Within tight time limits the department started devising fundamentally new educational programmes for bachelors, masters, and later for graduate students. Academic curricula and schedules of the educational process were compiled, preparation of educational-methodical complexes and student training manuals was started. Relying on the substantial and methodological foundation that was laid by Nadezhda Ivanovna Sergeeva and her colleagues V. P. Gritskevich and L. M. Shlyakhtina who were at the very origin of the department,the team in fact began creating a new "structure" of museological education in terms characterized by multiple controversies and crisis manifestations. The Associate Professor E. N. Mastenitsa was in charge of this work.

\section{1: Department of Museology and Cultural Heritage}

In connection with the transition to a multilevel system of training museum professionals in 2011 the Department of Museum Studies and Excursion Guiding decided to change the name and became known as the Department of Museology and Cultural Heritage. The renaming of the department was not a formal matching the title to the transformed profile of bachelor's and master's training - 
"Museology and Protection of Objects of Natural and Cultural Heritage", but was caused by more serious reasons. Firstly, by the desire to meet the trend of the current stage of intensive development of museology as an interdisciplinary sphere of knowledge about the global, national and regional heritage; museum ways and forms of its preservation and interpretation, ways of its actualization in modern culture, methods of museumification of objects of cultural and natural heritage. In other words, the expansion of the boundaries of the museum world and the concept of heritage modifies the paradigm of museology as a science that defines the conceptual and methodological basis for training a museum specialist. Secondly, by the need to respond to the current state of the international terminology of scientific and academic discipline in the educational practice of universities all over the world.

The change of name made it possible to expand the range of training profiles in the bachelor's and master's programmes, gave an additional impetus both to the development of graduate school as the third and the highest level of training of scholars and pedagogical faculty in the field of museology and cultural heritage and to programmes of continuing education. A new format revealed prospects that allow modernizing the areas of scientific research conducted at the department within the framework of course and final qualification papers of bachelors and masters, pushing the boundaries of the research topics of postgraduate students and degree seeking applicants and giving impetus to work of the student research society.

Since 2011, bachelor's training in museology has been carried out in two profiles: "Exhibition activity" and "Cultural tourism and excursion activities", master's - according to the profile "Management and expertise of cultural heritage", which results from the established traditions settled at the foundation of the department, relevance of these areas in development of museum practices, the growing role of a museum destination in tourism. Of no small importance in the choice of profiles was a highly qualified team of the teaching staff of the department, whose scientific and pedagogical potential will allow in the long term to change and broaden the profiles of training for both bachelors and masters. ${ }^{12}$

The transition to a multilevel training of museologists in the bachelor-master-postgraduate system has required a change in views on the structure, form and content of the educational process. It became obvious that it is necessary to concentrate efforts on developing the range of assessment and diagnostic tools, including those for the final state certification of bachelors and masters. Devising and implementing educational programmes involves serious work on updating and revising the methodological, organisational and technological support of higher education, improving practical training of bachelors and scientific expertise of masters.

However, despite all the problems and difficulties inevitable in the activities of any higher education institution department, all these three decades we have lived and worked as a united friendly team that can effectively solve complicated problems. The department prides itself on

\footnotetext{
12 MASTENITSA, Elena N. A museum specialist in the XXI century: a researcher? a curator? a museologist? Almanac of modern science and education. Reviewed comprehensive scientific-theoretical and applied journal, 2015, no. 9 (99), pp. 102-105.
}

a unique atmosphere of mutual respect and mutual understanding, a favorable environment is maintained for the creative development of each member of the faculty and realization of the personal potential of students and employees. Thus, Andrei Sergeevich Mukhin joined the department as a young faculty member without sufficient experience, academic degrees or titles, and over the years of persistent and inspired work has successfully defended the candidate's and then the doctor's dissertations and has deservedly become Professor of the Department of Museology and Cultural Heritage. We can note with satisfaction that in thirty years a formidable scientific research and educational foundation has been laid, the department has got its own traditions, values, and, most importantly, devoted people. It is gratifying that three of its graduates are part of faculty as Associate Professors, and several more people teach at the department part-time. We have got something to be proud of, because there is hardly a museum in St. Petersburg where you fail to come across our former students and graduate students who are currently directors or deputy directors, heads of departments and sectors of various museums and their branches, who run their own tourist companies or are well-known and popular excursion guides. Moreover, our graduates have achieved professional success in many foreign countries. We have brought up worthy successors and followers, which allows us to feel optimistic about the future. The 30th anniversary of the Department of Museology and Cultural Heritage will become not only a milestone marking an important stage of its formation, a stimulus for thoughtful reflection on the path that has been covered, but also a great 
holiday for everybody who serves it, who loves and remembers it. The jubilee is not just a wonderful and milestone anniversary, but it is also recognition of achievements, a balanced analysis of outcomes and a guarantee for effective further development. It will become an impulse to look for creative solutions to the tasks facing us and to acquire new meanings and horizons for scientific and pedagogical activity.

\section{REFERENCES}

GUBARENKO, Maria Ya. The influence of Z. Z. Stránský's ideas on the formation of the scientific school of the Department of Museology and Cultural Heritage of Saint Petersburg State Institute of Culture. Museologica Brunensia, 2016, vol. 5, no. 2, pp. 82-84. ISSN 1805-4722. GUBARENKO, Maria Ya. and Lyudmila M. SHLYAKHTINA. The genesis and formation of museology in the Czech Republic and its influence on the domestic scientific tradition. Problems of museology, 2015, No. 2 (12), pp. 3-16.

KUKLINOVA, Irina A. The concept of world history of museum activities in works of V. P. Gritskevich. In Bulletin of St. Petersburg University of Culture and Arts. Academic journal, 2016, No. 3 (28), pp. 112-115.
MASTENITSA, Elena N. A museum specialist in the XXI century: a researcher? a curator? A museologist? Almanac of modern science and education. Reviewed comprehensive scientific-theoretical and applied journal, 2015, No. 9 (99), pp. 102-105.

MASTENITSA, Elena N. Museum Reserves: a student training manual for bachelor's profile 51.03.04 "Museology and Protection of Objects of Cultural and Natural Heritage"; Ministry of Culture of RF, St. Petersburg State Institute of Culture, Faculty of World Culture, Department of Museology and Cultural Heritage. St. Petersburg: St. Petersburg State Institute of Culture, 2015. 132 p. MASTENITSA, Elena N. and Lyudmila M. SHLYAKHTINA. Institutionalization of science as a factor of development of museological education. In SIZOVA, I. A. (ed.). World cultural heritage and museums: history, problems and perspectives: materials of All-Russian scientific-practical conference with international participation (Tomsk, 18-20 May, 2017). Tomsk: Tomsk University Publishers, 2017, pp. 74-82.

SERGEEVA, Nadezhda I. Introductory article. In Museum and tourism: staff training. Experience and perspectives. Collection of materials of all-Russian scientific-practical conference 19-21 April 2004, devoted to 15th anniversary of the Department and 10th anniversary of the Faculty of Museum Studies and Excursion
Guiding. St. Petersburg: St. Petersburg State University of Culture and Arts, 2005, pp. 3-5.

SHLYAKHTINA, Lyudmila M. Basics of Museum Activities: Theory and Practice. St. Petersburg: Publishing House "Lan"; Publishing House "Planetamusyki", 2016. 248 p.

SHLYAKHTINA, Lyudmila M. and Elena N. MASTENITSA. Formation of the scientific school of the Department of Museology and Cultural Heritage of St. Petersburg State Institute of Culture. Bulletin of St. Petersburg University of Culture and Arts. Academic journal, 2016, No. 3(28), pp. 116-121.

SHLYAKHTINA, Lyudmila M. and Elena N. MASTENITSA. Museum-pedagogical thought in Russia. Historical Essays. St. Petersburg: St. Petersburg State University of Culture and Arts, 2006. 271 p.

STRÁNSKÝ, Zbyněk. Die theoretischen Grundlagen der Museologie als Wissenschaft. In Museologie: Neue WegeNeue Ziele. München [u. a.], 1989, pp. 38-47.

\section{ELENA MASTENITSA - LYUDMILA SHLYAKHTINA}

Department of Museology and Cultural Heritage, Saint Petersburg State Institute of Culture, Saint Petersburg, Russian Federation 